\title{
ANALISIS KESESUAIAN LOKASI BUDIDAYA RUMPUT LAUT (Eucheuma cottonii) DENGAN MENGGUNAKAN SISTEM INFORMASI GEOGRAFIS DI PERAIRAN TELUK AMBON BAGUALA
}

\section{(Analysis of The Suitability of Seaweed Cultivation Area (Eucheuma cottonii) by Using Geographic Information System in The Waters of Ambon Baguala Bay)}

\author{
Piter J. R. Lase ${ }^{1 *}$, S. F. Tuhumury ${ }^{2}$, dan H. J. D. Waas ${ }^{3}$ \\ 1) Mahasiswa Program Studi Magister Ilmu Kelautan Pascasarjana Universitas Pattimura \\ 2) Jurusan Budidaya Perairan Fakultas Perikanan dan Ilmu Kelautan Universitas Pattimura \\ 3) Jurusan Ilmu Kelautan Fakultas Perikanan dan Ilmu Kelautan Universitas Pattimura \\ *pieterlase06@gmail.com,sftuhumury@yahoo.co.id,harold.waas@fpik.unpatti.ac.id \\ Corresponding author*
}

\begin{abstract}
ABSTRAK: Teluk Baguala merupakan kawasan yang memiliki potensi sumberdaya perikanan yang cukup melimpah. Penentuan lokasi lahan budidaya perikanan laut harus didasarkan pertimbangan ekologis, teknis, higienis, sosio-ekonomis, dan ketentuan peraturan perundang-undangan yang berlaku. Tujuan penelitian ini ialah menganalisis indikator biofisik dan kimia perairain Teluk Baguala serta menentukan lokasi budidaya rumput laut (Eucheuma cottonii) dalam kaitan penetapan zonasi budidaya rumput laut. Penelitian berlangsung dari Februari hingga Maret 2020 dilanjutkan dengan analisa laboratorium dan tabulasi data berdasarkan waktu yang ditetapkan. Analisis data yang di gunakan penelitian ini adalah metode Interpolasi Inverse Distance Weighted (IDW). Hasil penelitian menunjukan kesesuaian lahan budidaya di Teluk Baguala memperoleh 1048.296 ha atau 78.7\% untuk kelas sangat sesuai dan 282.483 ha atau 21.2\% untuk kelas sesuai. Dari semua kriteria kesesuaian lahan budidaya di Teluk Baguala, nitrat merupakan kriteria yang mempunyai parameter perairan masuk dalam kelas sangat sesuai secara keseluruhan.
\end{abstract}

Kata Kunci: Teluk Baguala, lahan budidaya, rumput laut, kesesuaian, SIG

ABSTRACT: Baguala Bay is a high potential area with a rich fishery resources. Marine aquaculture field area should be determined by considering the ecological, technical, hygienic, socio-economic conditions simultaneously to the laws and regulation. The research is done in order to analyze chemical and biophysical indicators in the waters of Baguala Bay and to determine seaweed (Eucheuma cottonii) cultivation area considering the determination of seaweed cultivation zone. The result is done in February to March 2020 continues by laboratory analysis and data tabulation based on the time schedule. Interpolation Inverse Distance Weighted (IDW) is used to analyze data. The result shows the suitability cultivation area in Baguala Bay is 1048.296 ha or $78.7 \%$ is in high suitable rate and 282.483 ha or $21.2 \%$ is in suitable rate. Among all of the criteria of suitable cultivation area in Baguala Bay, nitrate is the criteria with the high suitability parameter overall.

Keywords: Baguala Bay, cultivation area, seaweed, suitability, GIS 


\section{PENDAHULUAN}

Perairan Kota Ambon memiliki potensi kelautan dan perikanan yang dapat diandalkan dan sangat menjanjikan (Siahainenia, $d k k$, 2017; Kaihatu, 2018). Potensi perikanan tangkap meliputi luas wilayah laut $136.116,1$ $\mathrm{km}^{2}$ dengan panjang garis pantai $1.256 .230 \mathrm{~km}^{2}$ dari wilayah 147.480,6 km (BPMD, 2007). Hal tersebut membuktikan bahwa Teluk Baguala merupakan kawasan yang memiliki potensi sumberdaya perikanan yang cukup melimpah yang didukung dengan ekosistem yang baik. Perairan Teluk Baguala memiliki potensi pengembangan sumberdaya perikanan budidaya. Pemilihan lokasi pengembangan usaha budidaya merupakan syarat utama yang secara teknis harus dipenuhi.

Pemilihan dan penentuan lokasi lahan budidaya perikanan laut harus didasarkan pada pertimbangan ekologis, teknis, higienis, sosioekonomis, dan ketentuan peraturan perundangundangan yang berlaku (Radiarta, dkk., 2015; Lumi, $d k k .$, 2019). Pemilihan lokasi seharusnya dilakukan dengan mempertimbangkan gabungan beberapa faktor yang dikaji secara menyeluruh. Usaha komoditas ini perlu disesuaikan dengan daya dukung lahan dan tata ruang potensi dari suatu hamparan atau kawasan, yang pada akhirnya dapat menjadikan kegiatan yang berkesinambungan.

Sistem Informasi Geografis (SIG) menjadi solusi yang baik dalam penentuan lokasi budidaya di pesisir dan laut (Sirza, $d k k$., 2014; Radiarta, $d k k ., 2017)$. Oleh karena itu, sistem informasi geografis juga dapat digunakan untuk pengembangan budidaya rumput laut (Ferdiansyah, dkk., 2019; Damis, dkk., 2020), karena SIG merupakan sistem informasi berbasis komputer yang digunakan untuk mengolah dan menyimpan data atau informasi geografis (Juniardi\&Azwansyah, 2014; Annugerah, dkk., 2016). Pada dasarnya SIG berintegrasi didasarkan pada 4 komponen, yaitu: hardware, software, manusia dan data. Sistem informasi geografis merupakan sarana untuk mengumpulkan, menggabungkan, dan mengolah data dari setiap parameter yang diperlukan. Keberadaan SIG dapat mempermudah pengolahan data dengan struktur yang kompleks dan jumlah yang besar secara efisien serta dapat membantu proses pengambilan keputusan yang tepat (Putri, dkk., 2014; Arismunandar, 2017).

Penzonasian wilayah perikanan budidaya dalam penataan ruang diharapkan dapat menghindarkan sektor budidaya dari sektor lain yang tidak berkesesuaian, sehingga pengembangan budidaya dapat menguntungkan dan berkelanjutan. Tujuan penelitian ini adalah menganalisis indikator biofisik dan kimia perairan Teluk Baguala serta menentukan lokasi budidaya rumput laut dalam kaitan penetapan zonasi budidaya rumput laut.

\section{METODE PENELITIAN}

Penelitian berlangsung dari Februari hingga Maret 2020 di perairan Teluk Baguala Kota Ambon, yang terbagi menjadi beberapa tahapan berbasis sub-zona budidaya laut. Pengumpulan data potensi ruang yang digunakan dalam penelitian ini adalah data primer dan data sekunder, dimana data primer diperoleh melalui observasi lapangan serta data citra satelit. Penelitian dilanjutkan dengan analisa laboratorium dan tabulasi data berdasarkan time schedule. Analisis data yang digunakan dalam penelitian ini adalah metode Interpolasi Inverse Distance Weighted (IDW). Metode ini merupakan metode deterministik yang sederhana dengan mempertimbangkan titik di sekitarnya (NCGIA, 2007). Metode interpolasi IDW mengasumsikan bahwa semakin dekat jarak suatu titik terhadap titik yang tidak diketahui nilainya, maka semakin besar pengaruhnya. IDW menggunakan nilai yang terukur pada titik-tiik di sekitar lokasi tersebut, untuk memperkirakan nilai variabel pada lokasi yang dimaksud. 


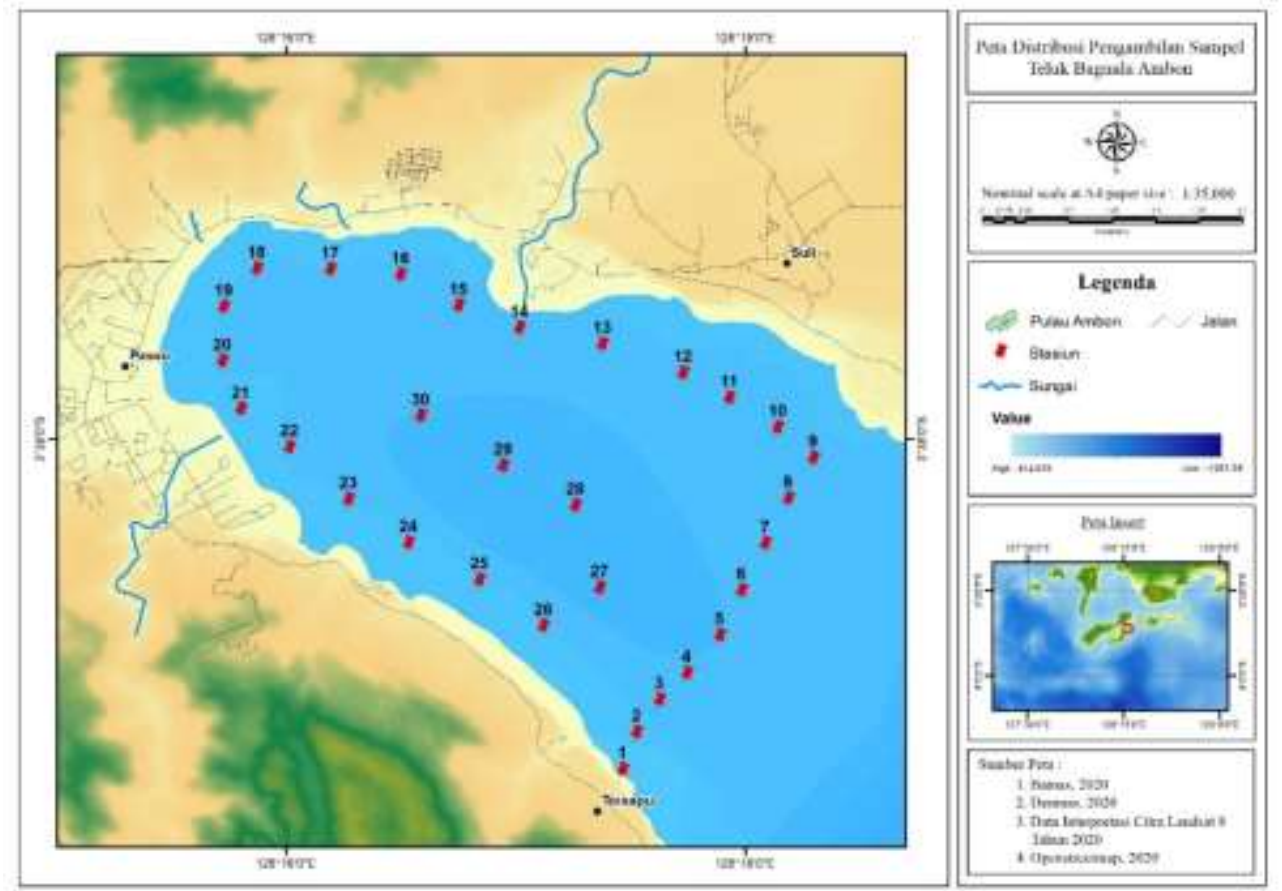

Gambar 1. Peta lokasi penelitian

\section{HASIL DAN PEMBAHASAN}

\section{Parameter Kesesuaian Lahan Budidaya Rumput Laut}

1. Gelombang

Parameter gelombang sangat berpengaruh terhadap budidaya rumput laut, baik mengenai transport nutrien maupun kebersihan permukaan tanaman dari substrat yang menempel. Lokasi dengan gelombang yang besar umumnya tidak sesuai bagi budidaya rumput laut, karena dapat memindahkan rumput laut dari media budidayanya serta dapat merusak media budidaya rumput laut yang digunakan. Menurut Wulandari, $d k k$. (2015), gelombang yang tinggi dan kecepatan arus yang besar dapat membuat rumput laut mudah patah. Gelombang yang berada pada perairan Teluk Baguala ini relatif tenang sekitar 0,19-0,61 m, karena pada perairan Teluk Baguala memiliki panjang garis pantai yang kecil.

2. Kecepatan Arus

Arus merupakan faktor yang harus diutamakan dalam pemilihan lokasi budidaya rumput laut karena arus yang kencang akan mempengaruhi sedimentasi dalam perairan, yang pada akhirnya mempengaruhi penetrasi cahaya matahari. Aliran air (water motion) diperlukan oleh rumput laut untuk dapat memperoleh makanan (nutrient) melalui aliran air yang melewatinya. Kecepatan arus yang sangat sesuai untuk penentuan lahan budidaya rumput laut adalah 20-40 cm/det. Kecepatan arus pada perairan Teluk Baguala sekitar 6,29$12,29 \mathrm{~cm} /$ det dan termasuk kriteria optimal untuk lahan budidaya rumput laut.

\section{Kecerahan}

Kecerahan perairan berhubungan dengan proses fotosintesis thallus rumput laut. Air yang keruh mengandung bahan tersuspensi yang melimpah akan menutupi thallus rumput laut sehingga menghambat penyerapan unsur hara. Sedikit banyaknya sinar matahari yang menembus ke dalam perairan sangat bergantung dari kecerahan air. Budidaya rumput laut dengan tingkat kecerahan yang tinggi sangat dibutuhkan, sehingga cahaya dapat masuk ke dalam air. Kecerahan yang ada pada Perairan Teluk Baguala kisaran $15.35 \mathrm{~m}$ sampai $0 \mathrm{~m}$ sehingga sangat cocok untuk budidaya rumput laut.

4. Suhu

Suhu merupakan salah satu faktor penting yang berpengaruh terhadap kelangsungan hidup dan pertumbuhan rumput laut. Suhu memiliki peranan dan fungsi untuk fisiologis rumput laut seperti fotosintesa, respirasi, metabolisme, 
pertumbuhan dan reproduksi. Kenaikan suhu dapat menyebabkan thallus rumput laut menjadi pucat kekuning-kuningan. Kondisi kisaran suhu menunjukkan bahwa wilayah penelitian Teluk Baguala mendapatkan kisaran toleransi hingga optimal dengan temperatur $29,84^{\circ} \mathrm{C}-32,16^{\circ} \mathrm{C}$.

5. $\mathrm{pH}$ Perairan

Derajat keasaman $(\mathrm{pH})$ adalah salah satu parameter lingkungan yang mempengaruhi organisme dalam perairan. $\mathrm{pH}$ suatu perairan merupakan faktor pembatas bagi organisme untuk dapat beradaptasi (Rohman, dkk., 2018). Nilai pH sangat penting diketahui karena banyak reaksi kimia dan biokimia yang terjadi pada tingkat $\mathrm{pH}$ tertentu. Perairan yang menerima limbah organik dalam jumlah yang besar berpotensi memiliki tingkat keasaman yang tinggi. Konsentrasi $\mathrm{pH}$ di lokasi berkisar antara 6,47-7,48. Berdasarkan data di perairan Teluk Baguala, kosentrasi pH Teluk Baguala termasuk dalam kriteria lahan dengan kisaran toleransi sampai di bawah baku mutu. Hasil tersebut menunnjukan hanya beberapa tempat di Teluk Baguala mengalami pencemaran, sehingga berdampak di perairan Teluk Baguala. 6. Salinitas

Salinitas merupakan salah satu parameter lingkungan yang penting untuk kelangsungan hidup suatu organisme termasuk rumput laut (Burdames\&Ngangi, 2014). Spesies Eucheuma cottonii merupakan jenis rumput laut yang bersifat stenohaline. Tumbuhan ini tidak tahan terhadap fluktuasi salinitas yang tinggi. Salinitas dapat berpengaruh terhadap proses osmoregulasi pada tumbuhan rumput laut. Kriteria yang cocok untuk budidaya rumput laut ini berkisar antara $28-37 \%$. Kandungan salinitas perairan Teluk Baguala adalah 27,06$40,29 \%$. Berdasarkan hasil uji laboratorium, kandungan salinitas pada stasiun 11 dan 12 merupakan kandungan salinitas tertinggi di antara stasiun yang lain. Berdasarkan data di perairan Teluk Baguala, kandungan salinitas Teluk Baguala termasuk dalam kriteria lahan dengan kisaran toleransi sampai di bawah baku mutu.

7. Oksigen Terlarut (DO)

Oksigen terlarut merupakan unsur penting yang diperlukan dalam melakukan proses respirasi dan menguraikan zat organik oleh mikroorganisme. Oksigen terlarut dalam air dapat berasal dari proses difusi dari udara dan hasil dari proses fotosintesis oleh fitoplankton dan tanaman air lainnya. Penambahan tekanan udara serta peningkatan suhu air dan salinitas, menyebabkan kelarutan oksigen rendah dan begitu pula sebaliknya. Hasil penelitian di Pantai Mlonggo, Jepara menunjukkan oksigen terlarut sebesar 3,2-7,8 mg.l yang cukup memadai untuk pertumbuhan rumput laut (Susilowati, $d k k ., 2012$ ). Oksigen Terlarut yang pada perairan Teluk Baguala kisaran $0 \mathrm{mg} / \mathrm{l}$ $9.06 \mathrm{mg} / \mathrm{l}$. Hasil data tersebut menggambarkan lokasi Teluk Baguala memiliki beragam kriteria kelayakan lahan.

8. Nitrat

Nitrat adalah bentuk utama nitrogen di perairan alami dan merupakan nutrien utama bagi pertumbuhan tanaman dan algae. Kadar nitrat menjadi salah satu kriteria kesesuaian perairan untuk lokasi budidaya rumput laut jenis Eucheuma cottonii, dikarenakan nitrat merupakan salah satu nutrien yang sangat dibutuhkan oleh rumput laut. Jika nitrat terlalu tinggi akan berdampak pada pertumbuhan rumput laut karena memunculkan algae sebagai kompetitor dalam mendapatkan nutrisi. Nitrat dapat digunakan untuk mengelompokkan tingkat kesuburan perairan yang terdiri dari perairan oligotrofik memiliki kadar nitrat antara 0-1 mg/l, perairan mesotrofik memiliki kadar nitrat antara 1-5 mg/l dan perairan eutrofik memiliki kadar nitrat yang berkisar antara 5-50 mg/l (Effendi, 2003). Kandungan nitrat di perairan Teluk Baguala diperoleh berkisar antara $0,65 \mathrm{mg} / \mathrm{l}$ sampai $0,27 \mathrm{mg} / \mathrm{l}$.

9. Fosfat

Fosfat merupakan salah satu unsur hara yang penting bagi metabolisme sel tanaman. Kandungan phospat mempengaruhi tingkat kesuburan perairan (Susilowati, $d k k$., 2012). Menurut Fikri, $d k k$. (2015), nilai kandungan fosfat yang berkisar antara 0,37-0,66 mg/l masih dalam kategori layak untuk kegiatan budidaya rumput laut. Kandungan fosfat yang cocok untuk budidaya rumput laut berkisar 0.02-1 $\mathrm{mg} / \mathrm{l}$. Seperti halnya nitrat, manfaat fosfat bagi pertumbuhan rumput laut tidak dapat digantikan dengan unsur yang lain. Hal ini disebabkan karena peran dari nitrat sebagai penyusun 
protein dan fosfat sebagai penyedia akan energi (Putri, dkk., 2014). Semakin sering rumput laut menyerap nitrat dan fosfat yang terbawa aliran air yang masuk ke dalam media pemeliharaan, maka semakin meningkat nilai pertumbuhan dalam artian akan semakin meningkat juga kandungan nitrat dan fosfat di dalam tubuh rumput laut. Kandungan fosfat perairan Teluk Baguala berkisar antara 0,029 mg/l-0,215 mg/l. Parameter kandungan fosfat pada perairan ini termasuk dalam kriteria toleran hingga di bawah baku mutu.

10. Total Padatan Tersuspensi (TSS)

Total padatan tersuspensi merupakan padatan yang terdapat pada larutan namun tidak terlarut. Penyebaran TSS di perairan pantai dan estuari dipengaruhi oleh beberapa faktor fisik antara lain angin, curah hujan, gelombang, arus, dan pasang surut (Effendi, 2003). (Sastrawijaya, 2000) menyatakan bahwa konsentrasi TSS dalam perairan umumnya terdiri dari fitoplankton, zooplankton, limbah manusia, limbah hewan, lumpur, sisa tanaman dan hewan, serta limbah industri. Menurut Effendi (2003), bahan-bahan yang tersuspensi di perairan alami tidak bersifat toksik, akan tetapi jika jumlahnya berlebihan dapat meningkatkan nilai kekeruhan yang selanjutnya menghambat penetrasi cahaya matahari ke kolom air. Nilai TSS dapat dipengaruhi oleh musim dimana konsentrasi TSS maksimum diperoleh ketika musim hujan berlangsung dan sebaliknya. Kosentrasi TSS pada lokasi penelitian ini berkisar antara 3,08 $\mathrm{mg} / \mathrm{l} \mathrm{sampai} 7,50 \mathrm{mg} / \mathrm{l}$.

\section{Analisis Kesesuaian Lokasi Budidaya Rumput Laut}

Budidaya perikanan laut khususnya rumput laut akan semakin berkembang dengan memilih lokasi yang sesuai berdasarkan parameter pendukungnya. Pemilihan lokasi ideal merupakan faktor penting untuk menunjang kelayakan usaha budidaya. Perubahan ekosistem baik komponen fisik, biologi maupun kimia dapat berdampak terhadap laju pertumbuhan dan produktivitas rumput laut. Dalam pengelolaan kawasan budidaya laut khususnya budidaya rumput laut dan ikan yang merupakan bagian dari pengelolaan pesisir, maka digunakan kebijakan pemerintah daerah yaitu rencana pengelolaan pesisir dan laut yang didalamnya juga mengacu pada RTRW Kota Ambon.

Hasil analisis spasial untuk kesesuaian lahan diperoleh luasan lahan perairan Teluk Baguala yang sesuai untuk budidaya rumput laut yang terdiri dari dua kelas, yaitu kelas sangat sesuai (S1) dengan luasan lahan sebesar 1048.296 ha atau 78,7\%. Lahan kelas S1 ini memiliki total nilai sebesar 345-268.34 dari nilai maksimum peruntukkan budidaya rumput laut. Kelas sesuai bersyarat (S2) dengan luasan sebesar 282.483 ha atau 21,2\%, lahan kelas S2 ini memiliki nilai total sebesar 268,33-191,67 dari nilai maksimum peruntukkan budidaya rumput laut (Gambar 2). Pada penelitian ini hasil kelas tidak sesuai (S3) tidak dapatkan. Dengan demikian kawasan perairan Baguala Ambon memenuhi kriteria lahan yang cukup luas untuk pengembangan budidaya rumput laut Eucheuma cottonii, sehingga memungkinkan mendapatkan jumlah produksi yang besar dengan mutu yang baik sesuai persyaratan tumbuh rumput laut.

\section{KESIMPULAN DAN SARAN}

Kesimpulan yang dirumuskan dari penelitian ini adalah sebagai berikut:

1. Indikator biofisik terbanyak yang masuk kelas sangat sesuai (S1) terdapat pada stasiun 24 dan stasiun 27 dengan 6 kriteria kesesuaian lahan budidaya. Parameter nitrat merupakan kriteria parameter perairan yang masuk dalam kelas sangat sesuai secara keseluruhan.

2. Hasil analisis spasial untuk kesesuaian lahan di Teluk Baguala, terdapat dua kelas serta luasan yang diperoleh untuk budidaya rumput laut antara lain: sangat sesuai (S1) sebesar 1048,296 ha atau sebesar 78,7\% dari keseluruhan area penelitian serta sesuai bersyarat (S2) sebesar 21,2\% dari keseluruhan area penelitian.

Saran dari penelitian ini adalah perlu dilakukan penelitian lanjutan tentang analisis daya dukung kawasan dalam rangka membangun model pengelolaan ruang yang berkelanjutan. 


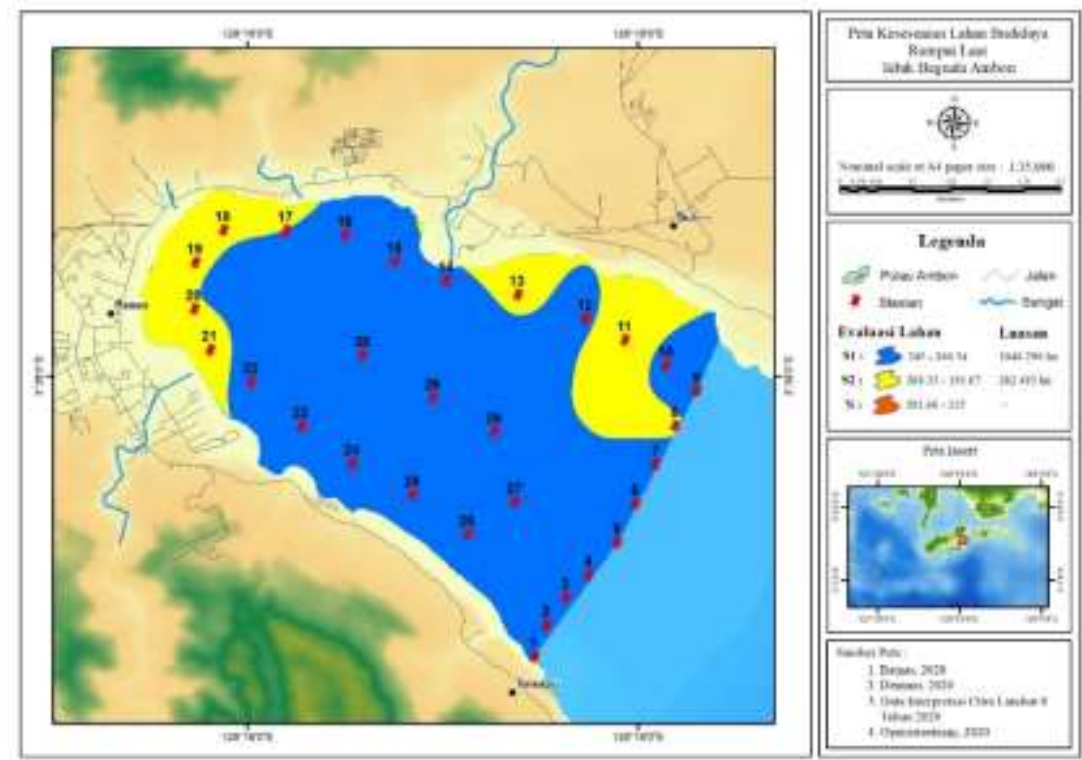

Gambar 2. Peta kesesuaian lahan budidaya rumput laut Teluk Baguala Ambon

\section{DAFTAR PUSTAKA}

Annugerah, A., I. F. Astuti, A. H. Kridalaksana. 2016. Sistem Informasi Geografis Berbasis Web Pemetaan Lokasi Toko Oleh-Oleh Khas Samarinda. Jurnal Informatika Mulawarman 11(2): 43-47.

Arismunandar, R. 2017. SIstem Informasi Geografis sebagai Alat Monitoring Terhadap Apotek Kerja Sama PT Bayer Indonesia. TEKNOSI 3(1): 187-198.

BPMD. 2007. Penanaman Modal di Maluku. BPMD Provinsi Maluku.

Burdames, Y. \& E.L.A. Ngangi. 2014. Kondisi Lingkungan Perairan Budidaya Rumput Laut di Desa Arakan, Kabupaten Minahasa Selatan. Budidaya Perairan 2(3): 69-75

Damis, Surianti, Hasrianti, A. R.S. Putri, Asmidar. 2020. Aplikasi Sistem Informasi Geografis Dalam Penentuan Lokasi Budidaya Rumput Laut di Pesisir Kecamatan Suppa, Kabupaten Pinrang. Albacore 4(2): 119-124.

Effendi, H. 2003. Telaah Kualitas Air: Bagi Pengelolaan Sumberdaya dan Lingkungan Perairan. Penerbit Kanisius Yogyakarta.

Ferdiansyah, H.I., I. Praktikto, Suryono. 2019. Pemetaan Kesesuaian Lahan untuk Budidaya Rumput Laut di Perairan Pulau Poteran, Kabupaten Sumenep, Jawa Timur. Journal of Marine Research 8(1): 36-40.

Fikri, M., S. Rejeki, L.L. Widowati. 2015. Produksi Kualitas Rumput Laut (Eucheuma cottonii) dengan Kedalaman Berbeda di Perairan Bulu
Kabupaten Jepara. Journal of Aquaculture Management and Technology 4(2): 67-74.

Juniardi, F. \& H. Azwansyah. 2014. Penyusunan Sistem Informasi Geografis Infrastruktur Transportasi Kabupaten Kapuas Hulu Berbasis WEB. Jurnal ELKHA 6(1): 6-12.

Kaihatu, M.M. 2018. Kontribusi Sektor Perikanan Dalam Perekonomian Kabupaten Maluku Tengah. Jurnal Matematika, Saint dan Teknologi 19(1): 57-71.

Lumi, K.W., U.N.W.J. Rembet, S. Darwisito. 2019. Kajian Ekologi-Ekonomi Budidaya Ikan Kuwe (Caranx sp) di Kecamatan Lembeh Utara Kota Bitung Provinsi Sulawesi Utara. Jurnal Ilmiah Platax 7(1): 121-133.

NCGIA. 2007. Interpolation Inverse Distance Weighting. http://www.ncgia. ucsb.edu/pubs/spherekit/inverse.html. Diakses 11 Juli 2020.

Putri, A.P.S., M.S. Utama, R. N. Rachmania, R.P. Soesanto. 2014. Perancangan Sistem Pendukung Keputusan dan Sistem Informasi Geografis Pemberian Bantuan Korban Banjir di Kabupaten Bandung Selatan. Seminar Nasional IENACO. Hal 318-326. ISSN 23374349.

Putri, F.D.M., E. Widyastuti, Christiani. 2014. Hubungan Perbandingan Total Nitrogen dan Total Fosfor Dengan Kelimpahan Chrysophyta di Perairan Waduk Panglima Besar Soedirman, Banjarnegara. Scripta Biologica 1(1): 96-101.

Radiarta, I.N., S. E. Wardoyo, B. Priono, O. Praseno. 2017. Aplikasi Sistem Informasi 
Geografis untuk Penentuan Lokasi Pengembangan Budidaya Laut di Teluk Ekas, Nusa Tenggara Barat. Jurnal Penelitian Perikanan Indonesia 9(1): 67-80.

Radiarta, I.N., Erlania, J. Haryadi. 2015. Analisis Pengembangan Perikanan Budidaya Berbasis Ekonomi Biru dengan Pendekatan Analytic Hierarchy Process (AHP). Jurnal Sosek KP 10(1): 47-59.

Rohman, A., R. Wisnu, S. Rejeki. 2018. Penentuan Kesesuaian Wilayah Muara Gembong, Kabupaten Bekasi untuk Lokasi Pengembangan Budidaya Rumput Laut dengan Pemanfaatan Sistem Informasi Geografis (SIG). Jurnal Sains Akuakultur Tropis 2(2018)1: 73-82.

Sastrawijaya, A.T. 2000. Pencemaran Lingkungan. Rineka Cipta. Jakarta.

Siahanienia, S.M., J. Hiariey, MS. Baskoro, W. Waileruny. 2017. Pemanfaatan Optimal Sumberdaya Cakalang di Perairan Maluku.
TRITON: Jurnal Manajemen Sumberdaya Perairan 13(2): 125-134.

Sirza, L.O.M.J., A. Hartoko, Suminto. 2016. Analisis Kesesuaian Lokasi dan Data Spasial Budidaya Laut Berdasarkan Parameter Kualitas Perairan di Teluk Lasongko Kabupaten Buton Tengah. Seminar Nasional Inovasi dan Aplikasi Teknologi di Industri (SENIATI). Hal 80-84.

Susilowati, T., S. Rejeki, E. N. Dewi, Zulftriani. 2012. Pengaruh Kedalaman Terhadap Pertumbuhan Rumput Laut (Eucheuma cottonii) yang Dibudidayakan dengan Metode Longline di Pantai Mlonggo, Kabupaten Jepara. Jurnal Saintek Perikanan 8(1): 7-12.

Wulandari, S.R., S. Hutabarat, Ruswahyuni. 2015. Pengaruh Arus dan Substrat Terhadap Distribusi Kerapatan Rumput Laut di Perairan Pulau Panjang Sebelah Barat dan Selatan. Diponegoro Journal of Maquares 4(3): 91-98. 